\title{
FAKTOR-FAKTOR YANG MEMPENGARUHI KEGAGALAN USAHA
}

\author{
Mukhlishotul Jannah \\ IAIN Sultan Maulana Hasanuddin Banten
}

\begin{abstract}
Abstrak. Faktor-Faktor Yang Mempengaruhi Kegagalan Usaha. Perubahan kondisi ekonomi makro dapat mempengaruhi kelangsungan hidup suatu perusahaan. Ketika terjadi krisis ekonomi pada pertengahan tahun 1997, banyak perusahaan yang mengalami kesulitan keuangan dan bahkan beberapa diantaranya mengalami kebangkrutan. Krisis keuangan global yang terjadi pada akhir tahun 2008 pun berdampak pada kelangsungan hidup perusahaan diberbagai negara. Kelangsungan hidup suatu perusahaan tidak hanya dipengaruhi oleh kondisi di luar perusahaan, tetapi juga oleh pengelolaan perusahaan yang kurang baik. Suatu perusahaan tidak selalu berkembang dengan baik sebagaimana diharapkan. Dalam praktik, banyak perusahaan yang mengalami kegagalan. Kegagalan bisnis tidak terbatas pada satu industri atau perusahaan tertentu, tapi dapat dialami oleh semua industri atau perusahaan. Ada berbagai faktor yang dapat menyebabkan perusahaan mengalami kegagalan, diantaranya adalah faktor ekonomi, kesalahan manajemen, dan bencana alam. Perusahaan yang mengalami kegagalan dalam operasinya akan berdampak pada kesulitan keuangan perusahaan. Ada banyak faktor yang mengakibatkan perusahaan mengalami kesulitan keuangan, tapi kebanyakan penyebabnya, baik langsung atau tidak langsung adalah karena kesalahan manajemen yang terjadi berulang-ulang. Akumulasi ketidakmampuan manajemen dalam mengelola perusahaan inilah yang akhirnya mengakibatkan kegagalan perusahaan.
\end{abstract}

Kata Kunci: Kegagalan Usaha, Kesalahan Manajemen.

Abstract. The Factors of Business Failure. The changes in macroeconomic conditions may affect the survival of a company. There are many companies which struck a snag financially when economic crisis on middle year 1997, and some of them into bankruptcy. On the year end of 2008, global financial crisis at various states caused on company viability. The viability of a company not only based on the external factors, but also caused by internal company management. An enterprise is not always good developed as expected but in practice many companies have failed on business. Business failure is not limited to one industry or a particular company, but can be experienced by all industries or companies. There are various factors can cause business failure, such as economic factors, management fault, and natural disasters. The failure of companies will have an impact on the company's financial difficulties. There are many factors that lead the companies into financial difficulties, but most of factor either directly or indirectly is due to management errors happen repeatedly. Lastly, the accumulation of management incompetence in managing the company that finally resulted in the failure of company.

Key Words: failure, busines, management errors. 


\section{PENDAHULUAN}

Suatu perusahaan tidak selalu berkembang dengan baik sebagaimana diharapkan. Dalam praktik, banyak perusahaan yang mengalami kegagalan. Kegagalan bisnis tidak terbatas pada satu industri atau perusahaan tertentu, tapi dapat dialami oleh semua industri atau perusahaan.

Kegagalan usaha sebenarnya bisa menjadi tonggak awal menuju sukses. Dengan kegagalan, kita dapat belajar dari kesalahan dan lebih mapan pengalaman. Banyak perusahaan semakin maju setelah didera masalah. Garuda Indonesia contohnya. Di era 2007-an, maskapai penerbangan yang menjadi kebanggaan rakyat Indonesia ini sempat dilarang terbang di wilayah Uni Eropa selama dua tahun karena tingginya angka kecelakaan. Namun larangan tersebut justru memecut Garuda Indonesia untuk terus berbenah hingga akhirnya sukses menyabet penghargaan tertinggi sebagai The Best International Airline (Akhlis, 2013).

Garuda Indonesia hanyalah satu dari sekian banyak perusahaan yang berhasil terbang tinggi setelah terjatuh. Meskipun demikian, apakah kita harus selalu mengandalkan kegagalan untuk belajar? Mungkinkah menghindari kegagalan? Jalan termudah untuk menghindari kegagalan adalah dengan cara mengenali kegagalan itu sendiri.

\section{KEGAGALAN DAN KEBERHASILAN}

Apa makna kegagalan? Jawaban paling sederhana adalah ketidakberhasilan. Menurut Kamus Besar Bahasa Indonesia, gagal adalah tidak berhasil, tidak tercapai maksudnya (KBBI, 2014). Kegagalan berkebalikan dengan keberhasilan. Tidak berhasil berarti pula tidak tercapainya target yang telah ditetapkan. Karena adanya target untuk dapat dipakai sebagai pengukur suatu keberhasilan. Maka dari itu selalu ada kriteria-kriteria sebagai parameter guna menentukan, apakah suatu target telah tercapai atau belum tercapai. Dari logika ini dapatlah ditarik suatu pengertian, kegagalan adalah tidak tercapainya target yang telah ditetapkan. Itu berarti, ketiadaan target akan meniadakan pula kegagalan. Maksudnya, tidaklah dapat seseorang itu dinyatakan gagal tentang sesuatu bilamana seseorang tersebut tidak memiliki target yang diharapkan (Mono, 2013). 
Kegagalan adalah cara Allah SWT mengajarkan kita tentang pantang menyerah, kesabaran, kerja keras dan percaya diri. Tugas kita adalah focus pada mengais hikmah dari setiap peristiwa yang mampir dalam kehidupan kita.

Gagal adalah sebuah kemenangan yang tertunda atau keinginan yang belum tercapai. Biasanya kegagalan disebabkan karena kita tidak mengetahui definisi atau arti dari belajar. Sesungguhnya kegagalan tidak jauh berbeda dengan "belum berhasil“. Kita tidak akan pernah tahu kita berhasil kalau kita tdk pernah gagal. yang terpenting bukanlah berapa sering kita gagal atau jatuh, tapi seberapa seringkah ktia bangkit setiap kita gagal atau jatuh.

Kegagalan adalah hal yang lumrah dalam berusaha. Statistik membuktikan hampir 50\% usaha pemula mengalami kegagalan, terutama di lima tahun pertama memutar roda usaha.Namun demikian kegagalan bisa menjadi tonggak awal menuju sukses. Kegagalan adalah awal dari kesuksesan dan apabila seseorang menyerah dari kegagalan berarti dia tidak tahu bahwa kesuksesan sudah sangat dekat dua kalimat ini seharusnya bisa menyadarkan kita untuk tidak pernah menyerah. Dengan kegagalan, kita dapat belajar dari kesalahan dan lebih mapan pengalaman sehingga keberhasilan dapat tercapai.

Keberhasilan usaha adalah suatu keadaan dimana usaha mengalami peningkatan dari hasil yang sebelumnya. Keberhasilan usaha merupakan tujuan utama dari sebuah perusahaan, dimana segala aktivitas yang ada di dalamnya ditujukan untuk mencapai suatu keberhasilan.

Dalam pengertian umum, keberhasilan usaha menunjukkan suatu keadaan yang lebih baik/unggul dari pada masa sebelumnya. Keberhasilan usaha adalah sesuatu keadaan yang menggambarkan lebih daripada lainnya yang sederajat atau sekelasnya.

Menurut Suyanto keberhasilan usaha industri kecil di pengaruhi oleh berbagai faktor. Kinerja usaha perusahaan merupakan salah satu tujuan dari setiap pengusaha. Kinerja usaha industri kecil dapat diartikan sebagai tingkat keberhasilan dalam pencapaian maksud atau tujuan yang diharapkan. Sebagai ukuran keberhasilan usaha suatu perusahaan dapat dilihat dari berbagai aspek, seperti: kinerja keuangan dan image perusahaan (Chamdan, 2010). Menurut Sony Heru Priyanto Seseorang yang 
memiliki kewirausahaan tinggi dan digabung dengan kemampuan manajerial yang memadai akan menyebabkan dia sukses dalam usahanya (Priyanto, 2009).

Selain itu, keberhasilan usaha dapat dilihat dari target yang dibuat oleh pengusaha. Hal ini seperti yang terungkap oleh Dalimunthe dalam Edi Noersasongko yang menyatakan bahwa kita dapat menganalisis keberhasilan usaha dengan mengetahui kinerja suatu perusahaan yang dapat dirumuskan melalui suatu perbandingan nilai yang dihasilkan perusahaan dengan nilai yang diharapkan dengan memanfaatkan sumberdaya yang dimiliki. Kinerja perusahaan adalah output dari berbagai faktor di atas yang oleh karenanya ukuran ini menjadi sangat penting untuk mengetahui tingkat adaptabilitas bisnis dengan lingkungannya. Kinerja usaha perlu dihubungkan dengan target perusahaan yang ditentukan oleh manajer-pemilik usaha. Apapun targetnya, kinerja usaha merupakan tolok ukur untuk menilai seberapa besar tingkat pencapaian suatu target atau tujuan usaha (Noersasongko, 2005).

Menurut Ina Primiana mengemukakan bahwa "Keberhasilan usaha adalah permodalan sudah terpenuhi, penyaluran yang produktif dan tercapainya tujuan organisasi" (Primiana, 2009). Henry Faizal Noor mengemukakan bahwa "Keberhasilan usaha pada hakikatnya adalah keberhasilan dari bisnis mencapai tujuannya, suatu bisnis dikatakan berhasil bila mendapat laba, karena laba adalah tujuan dari seseorang melakukan bisnis" (Noor, 2007).

Keberhasilan usaha didefinisikan sebagai tingkat pencapaian hasil atau tujuan organisasi (Riyanti, 2003). Lebih lanjut Riyanti mengatakan bahwa keberhasilan usaha yaitu usaha kecil berhasil karena wirausaha memiliki otak yang cerdas, yaitu kreatif, mengikuti perkembangan teknologi dan dapat menerapkan secara proaktif. Mereka juga memiliki energi yang melimpah serta dorongan dan kemampuan asertif.

Sehingga, dapat diketahui bahwa definisi keberhasilan usaha adalah keberhasilan dari bisnis mencapai tujuannya,dimana keberhasilan tersebut didapatkan dari wirausaha yang memiliki otak yang cerdas, yaitu kreatif, mengikuti perkembangan teknologi dan dapat menerapkan secara proaktif dan hal tersebut terlihat dari usaha dari wirausaha dimana suatu keadaan usahanya yang lebih baik dari periode sebelumnya dan menggambarkan lebih daripada yang lainnya yang sederajat atau sekelasnya, dapat dilihat dari efisiensi proses produksi yang dikelompokkan berdasarkan efisiensi secara teknis dan efisiensi secara ekonomis, 
target perusahaan yang ditentukan oleh manajer-pemilik usaha, permodalan, skala usaha, hasil atau laba, jenis usaha atau pengelolaan, kinerja keuangan, serta image perusahaan.

Untuk mencapai keberhasilan seseorang/usaha membutuhkan manajemen, atau tatanan tindakan sebagai langkah-langkah strategik agar target yang diharapkan tersebut tercapai. Dengan demikian manajemen bagi seseorang yang memiliki target sasaran menjadi sangat urgen. Itu berarti kemampuan di bidang manajemen tidak dapat lagi dipandang sebagai kebutuhan nomor dua, lebih dari itu ketrampilan ini justru menempati prioritas utama bagi setiap sosok manusia yang ingin berhasil. Singkatnya, dalam kerangka mencapai suatu keberhasilan, disyaratkan adanya ketrampilan manajemen yang sesuai dengan target sasaran atau gol yang diharapkan. Tidak terpenuhinya persyaratan yang disebut terakhir ini, dapat dipastikan bakal mengakibatkan kegagalan.

Kegagalan yang seringkali diterjemahkan sebagai wujud musibah, ternyata dalam wujudnya tidak sebagai peristiwa tunggal. Disebabkan adanya kegagalan, maka pada diri manusia yang tertimpa kegagalan itu dapat tertimpa pula bentukbentuk kegagalan-kegagalan yang lain sebagai efek domino. Dengan kata lain, dikarenakan adanya kegagalan timbullah masalah-masalah lain yang membutuhkan penyelesaian. Bilamana situasi yang membutuhkan penyelesaian tersebut ternyata mengalami hambatan-hambatan dalam upayanya mencari solusi, maka muncullah frustasi. Yakni, situasi terhambat pada kejiwaan seseorang dalam upayanya untuk pemuasan kebutuhan personal maupun karena tuntutan lingkungan.

\section{FAKTOR PENYEBAB KEGAGALAN USAHA}

Ada berbagai faktor yang dapat menyebabkan perusahaan mengalami kegagalan, diantaranya adalah faktor ekonomi, kesalahan manajemen, dan bencana alam. Perusahaan yang mengalami kegagalan dalam operasinya akan berdampak pada kesulitan keuangan perusahaan (Sudana, 2011).

Zimmerer mengemukakan ada beberapa faktor penyebab kegagalan dalam menjalankan usaha, yaitu :

1. Ketidakmampuan Manajemen; Dalam bisnis kecil, kurangnya pengalaman manajemen atau lemahnya kemampuan pengambilan keputusan merupakan 
masalah utama dari kegagalan usaha. Pemilik usaha kurang memiliki kemampuan kepemimpinan dan pengetahuan yang diperlukan agar bisnis bisa berjalan.

2. Kurang Pengalaman; Manajer bisnis kecil perlu memiliki pengalaman dalam bidang usaha yang akan dimasukinya. Idealnya, calon wirausahawan harus memilki keterampilan teknis yang memadai (pengalaman kerja mengenai konsep pengoperasian fisik bisnis dan kemampuan konsep yang mencukupi), kemampuan mengkoordinasi berbagai kegiatan bisnis, serta keterampilan untuk mengelola orang-orang dalam organisasi serta memotivasi mereka untuk meningkatkan kinerja.

3. Lemahnya Kendali Keuangan; Kunci dari keberhasilan bisnis adalah adanya kendali keuangan yang baik. Sementara itu, perusahaan kecil seringkali melakukan dua kesalahan keuangan, yakni kekurangan modal dan kelemahan dalam kebijakan kredit terhadap pelanggan.

4. Gagal Mengembangkan Perencanaan yang Strategis; Tanpa memiliki suatu strategi yang didefinisikan dengan jelas, sebuah bisnis tidak memiliki dasar yang berkesinambungan untuk menciptakan dan memelihara keunggulan bersaing di pasar.

5. Pertumbuhan Tidak Terkendali; Pertumbuhan merupakan sesuatu yang alamiah, sehat, dan didambakan oleh semua perusahaan. Namun demikian, pertumbuhan haruslah terencana dan terkendali. Hal itu dikarenakan cenderung meningkatnya berbagai masalah dengan berkembangnya perusahaan sehingga manajer harus belajar menangani masalah-masalah tersebut.

6. Lokasi yang Buruk; Pemilihan lokasi yang tepat harus dipilih berdasarkan penelitian, pengamatan, dan perencanaan. Selain itu, perlu juga dipertimbangkan besarnya biaya sewa yang harus dibayar. Beberapa pemilik bisnis seringkali memilih lokasi hanya dikarenakan adanya tempat yang kosong.

7. Pengendalian Persediaan yang Kurang Baik; Pada umunya, investasi terbesar yang harus dilakukan oleh manajer bisnis kecil adalah salah satu tanggung jawab menajerial yang penting. Tingkat persediaan yang tidak 
mencukupi akan mengakibatkan kekurangan dan kehabisan stok sehingga pelanggan merasa kecewa dan pergi.

8. Ketidakmampuan Membuat Transisi Usaha; Setelah berdiri dan berkembang, biasanya diperlukan adanya perubahan gaya manajemen yang secara drastis berbeda (Zimmerer, 2009).

Faktor lain yang menjadi penyebab kegagalan usaha adalah :

1. Tidak Memiliki Visi; Usaha yang dijalankan tanpa tujuan merupakan penyebab terbesar kegagalan. Oleh karenanya, menentukan suatu tujuan, baik untuk jangka panjang, menengah, atau pendek, adalah hal yang sangat penting dilakukan. Terlebih jika dalam menjalankan usaha, kita bekerjasama dengan satu atau beberapa rekan usaha. Menyamakan visi diawal usaha adalah suatu keharusan.

2. Lemahnya Perencanaan; Yang penting jalan dulu deh! Tapi, mau lewat mana? Pake apa? Perlu uang berapa? Disinilah pentingnya peran perencanaan. Perencanaan tidak harus rumit, tidak perlu seperti rencana perusahaan besar. Yang terpenting, bisa dijadikan pedoman untuk mencapai target. Ingat, jika gagal membuat rencana, sebenarnya kita sedang merencanakan sebuah kegagalan.

3. Terlalu Percaya Diri; Tidak semua ide besar akan booming di pasar. Sebelum ditawarkan ke konsumen, akan lebih 'aman' jika ide itu diuji dulu kelayakannya melalui sebuah riset atau cukup melakukan jajak pendapat sederhana kepada teman, keluarga, atau tetangga. Biarkan mereka menjawab dengan jujur dan menilai ide yang kita miliki.

4. Miskin Komitmen; Ide yang bernilai milyaran akan menjadi sia-sia jika tidak diimbangi dengan komitmen yang kuat. Banyak wirausaha yang sudah memulai usaha namun tidak memiliki waktu untuk mengelola perusahaan. Imbasnya, usaha mengalami stagnan, sulit berkembang dan akhirnya gagal. Hati-hati juga dengan keberhasilan. Seringkali keberhasilan membuat kita hanyut dalam euforia hingga melupakan komitmen.

5. Keterbatasan Dana; Salah satu penyebab kegagalan ditahun-tahun awal usaha adalah minimnya dana operasional. Seorang pemilik perusahaan, walaupun 
kecil, harusnya bisa menghitung berapa banyak dana yang dibutuhkan untuk memutar roda usaha selama belum menghasilkan. Siasati kondisi ini dengan struktur manajemen yang ramping, mengurangi pemborosan, meningkatkan efisiensi finansial yang berorientasi mendorong keuntungan.

6. Minimnya Kemampuan Manajerial; Banyak cerita kegagalan yang berakar dari minimnya pengalaman dan keterampilan manajerial seperti tidak mampu membuat perencanaan, salah mengelola keuangan, kurang jeli melihat pergerakan pasar, atau gagal memotivasi karyawan. Untuk mengejar ketinggalan ini, tak ada salahnya mengais ilmu dari berbagai seminar dan pelatihan manajemen. Bertukar pikiran dengan teman yang lebih dulu terjun ke dunia usaha juga dapat dilakukan untuk mendongkrak kemampuan majerial (Ciputra, 2013).

Menurut Ipan Pranashakti, ada 7 hal penyebab kegagalan usaha/ bisnis secara umum, yaitu :

1. Kurangnya Pemahaman Usaha dan Tempat Usaha. Memahami secara kontekstual dan strategi bukan saja bagaimana produk itu mempunyai nilai tambah dan dibuat. Namun perlunya pemahaman akan kebutuhan masyarakat akan produk tersebut, baik secara frekuensi, kuantitas, bentuk/jenis dan kualitasnya. Pemahaman usaha juga berkaitan terhadap sarana dan prasarana misal lokasi usaha, info usaha, kondisi kelengkapan usaha. Misal saya ambil contoh, seorang ibu yang pandai sekali memasak belum tentu berhasil dalam usaha rumah makan karena bisnis tidak saja tentang pemahaman proses produksi saja. Misal lagi, tempat usaha yang disewa ratusan juta belum tentu akan membawa keberhasilan usaha, jika tidak mempunyai kedekatan pasar dan kemudahan akses (akses berbasis jangkauan fisik dan teknologi). Kedekatan lokasi dengan sumber bahan baku/sumber produksi juga menjadi bagian penting karena dapat mengefisiensikan biaya transportasi dan produksi.

2. Kurangnya Pengalaman dan Strategi Pemasaran. Kewirausahaan dalam kontek usaha masyarakat, tetap perlu ada pengalaman usaha. Kalo sekiranya pemodal dan pemilik belum pengalaman maka belilah orang untuk dijadikan staf 
atau partner usaha, baik secara aktif maupun konsultan. Pengalaman berhubungan dengan bagaimana menjual, kepada siapa menjual, mengikat pelanggan, menangkap reaksi pelanggan dan lain-lain. Secara umum masyarakat sebagai pelaku usaha, mampu dan giat dalam produksi, baik dalam usaha kerajinan, makanan, layanan jasa dan lain-lain namun tidak mempunyai kekuatan dan metode dan konsep pemasaran yang sistematis, ketika hari ini cukup laku maka tidak memperhitungkan kemungkinan bulan yang akan datang bahkan tahun-tahun mendatang. Rata-rata tidak mempunyai rencana pemasaran, bahkan rencana usaha atau bisnis plan, sehingga rencana peningkatan usaha juga tidak bisa dijadwalkan dan dipacu untuk dicapai.

\section{Kurangnya Pemahaman Dalam Pengadaan dan Pemeliharaan Bahan Baku} dan Sarana. Pengadaaan bahan baku tidak serta merta seperti logika membeli bahan baku cabe, daging dalam rumah makan atau logika semen, besi dalam usaha bangunan, tetapi lebih kepada bagaimana bahan baku diperlakukan. Banyak pebisnis yang baru membuka usaha membeli bahan baku sebanyak mungkin namun tidak dengan pemahaman bagaimana bahan baku dipelihara, serta pemahaman frekuensi penggunaan bahan baku harian, mingguan dan permintaan masyarakat .Contoh lain lagi, pemahaman sarana, banyak pengusaha dalam bidang digital printing membeli alat jutaan bahkan ratusan juga impor, namun tidak paham bagaimana memelihara dan antisipasi hariannya secara rutin dan strategis, sehingga keseringan rusak menimbulkan ketergantungan teknisi dari luar kota dan luar negeri, membuat usaha macet ketika alat rusak. Sehingga banyak order yang di batalkan dan pelanggan pun lari. Padahal ada beberapa penyedia sarana digital printing yang memberikan layanan garansi secara pasti sampai ke mendatangkan teknisinya dari China sana walaupun harga lebih mahal, ini semua hasil studi kasus di pebisnis digital printing di Yogya.

4. Kurangnya Kehandalan Pengelolaan Administrasi dan Keuangan. Kebijakan dalam menentukan keputusan strategi berwirausaha hendaknya tidak mengandalkan dari insting dan naluri saja. Namun histori dalam catatan administrasi perlu di jadikan modal dalam menentukan keputusan. 
Kebijakan/Keputusan berbasisis data. Begitu juga dalam hal keuangan, banyak kasus usaha yang dirintis tidak mempunyai kekuatan data keuangan yang baik, sehingga pemilik tidak paham akan pendapatan rutin bulanan, tidak bisa mengkorelasi antara pendapatan, penjualan dan penggunaan bahan baku. Sehingga kemungkinan penyalahgunaan di tingkat bawah bisa dijalankan tanpa diketahui.

\section{Kurangnya Kehandalan Pengelolaan Modal dan Kendali Kredit.}

Wirausahawan yang baik memahami modal tidak saja uang. Sehingga kredit yang membabi buta ke bank-bank bukan salah satu solusi tunggal, apalagi mengambil kredit maksimal dari plafon jaminannya, yang tidak diperhitungkan dari kebutuhan operasional. Pengusaha mikro banyak menjadi kan kredit sebagai expansi produksi dan pra investasi. Tidak akurasi dalam memperhitungkan kebutuhan suntikan modal dengan kemampuan bayar bulanan dan skala likuditas nya. Likuiditasnya misal apakah pelanggan anda selalu membayar tunai atau menunda-nunda pembayaran. Dengan kata lain, ketika anda mengajukan kredit ke bank, tentu andapun juga harus hati-hati dalam memberikan kredit atau pending payment kepada pelanggan anda, pilah-pilah mana yang tertib dan tidak, lalu tentukan sikap skala prioritasnya. Pemodalan yang semu dan tidak terpisah dengan kepentingan/ kebutuhan pribadi juga menjadi awal kegagalan usaha, penarikan dana dari perusahaan/ toko terlalu sering dan cepat namun tidak memperhitungkan dengan arus pembayaran dan pendapatan perusahaan/ toko/ usaha.

6. Kurangnya Kehandalan SDM yang Berwawasan Wirausaha. Wirausahawan yang sejati tidak serta merta menjadikan seluruh keluarganya adalan staf dari perusahaan/toko/usahanya. Kenapa? Karena hubungan yang terlalu cair dalam keluarga dapat menghilangkan kinerja fungsi stuktural yang seharusnya. Misal harusnya pimpinan berhak menegur proses pengelolaan pengadaaan barang yang sesuai standar, namun karena staf yang bertanggungjawab adalah adik ipar, maka segan untuk menegur, dan beranggapan bahwa nanti tentu akan berubah. SDM yang berwawasan wirausaha maka akan membentuk jiwa yang kokoh, karena 
beranggapan bahwa selain dia staf namun juga sosok yang yakin bahwa dengan sukses di bidangnya maka dia telah berhasil sebagai wirausahawan layaknya pemilik usaha, walau hanya dalam area kerjanya, seakan-akan bekerja sukses juga kepuasan pribadi dan teamwork. Sehingga staf mempunyai daya tahan terhadap masalah yang timbul, karena beranggapan bahwa masalah adalah bagian dari proses berwirausaha. Caranya, jangan jadikan staf anda seorang robot yang harus turut pada perintah namun juga diberikan tantangan untuk analisa perbaikan, dan ada reward periodik, inilah hal yang tidak dilakukan penguasa secara umum, dan salah satu kegagalan dalam skop SDM. Memasukkan nilai kewirausahaan menyatu dalam motivasi kerja bawahan bukan hal yang mudah, tetapi jika anda memberikan tantangan dan standar pencapaian per unit, maka itu salah satu bentuk pendidikannya, tinggal metode harmonisasinya antara divisi. Kekurangan dalam menentukan kualifikasi staf dalam rekrutmen merupakan sebagian penyebab kegagalan dalam usaha peningkatan keberlangsungan usaha. Sehingga perencaaan usaha yang baik selalu menyiapkan kriteria SDM masing-masing divisi baru melakukan rekrutmen. Jangan terbalik.

7. Kekurangan Pemahaman Perubahan Teknologi. Pemahaman teknolgi bagi SDM tidak serta merta harus berkaitan dengan komputer dan internet, namun juga berdasar kemudahan dari dampak teknologi yang ada, misal mengulek sambel dari cobek beralih dengan blender, dari penghangat nasi dengan kompor beralih ke magic jar. Sekarang kalo dalam bidang cetak mencetak, yang dahulunya dengan mesin cetak warna yang mahal sekarang cukup dengan yang portable dan print namun tetap dengan kualitas handal. Kegagalan usaha pemahaman teknologi ini tidak semata karena pemahaman pembelian namun juga pemeliharaan, misal banyak data keuangan, data nasabah yang hilang karena virus, atau ketidakmampuan staf dalam melindungi data file konsumen sehingga ada pesaing yang bisa mengambil melalui salah satu stafnya yang hendak kena PHK atau pindah, sehingga data-data dengan mudah digunakan oleh pesaing. Teknologi juga berkaitan dengan prediksi kehandalan perangkat yang digunakan saat ini agar tetap survive dalam 5 s.d 15 tahun mendatang. serta hendaknya SDM harus mau belajar setiap saat untuk mengikuti perkembangan teknologi. 
Teknologi juga berakitan dengan keberhasilan pemasaran baik dalam mendesain grafis, pubklikasi profil dalam cd, membuat website atau blog gratis. Jangan berpikir bahwa usaha kecil pun tidak perlu website, karena beberapa waktu lalu saya mendesain sistem sebuah web untuk promosi kecil usaha jahit baju, saat ini order dari beberapa kota hasil promosi di website sudah mulai berdatangan (Pranashakti, 2014).

Beberapa hal yang juga patut diperhatikan guna menghindari kegagalan dalam usaha adalah: 1). Parttime vs Fulltime, seseorang yang berbisnis secara paruh waktu dengan yang fulltime akan mempunyai peluang yang berbeda untuk memajukan bisnisnya. Orang yang berbisnis sebagai sampingan akan terpecah konsentrasi, waktu, tenaga, dan tugasnya. Berbeda dengan yang sudah menjalankan usaha secara full, dia bisa fokus penuh pada bisnis yang sedang dijalankan dan hasilnya pasti berbeda. 2). Memperbesar skala usaha terlalu cepat. Memang bagus jika dilihat sebuah usaha berkembang dengan cepat, namun apakah sudah memiliki pondasi yang kuat? Untuk itu, diperlukan sumber daya manusia yang benar-benar bisa bekerja dengan baik dan loyal terhadap perusahaan. Setiap langkah yang dibuat perusahaan harusnya sesuai dengan model bisnis yang sudah matang terencana sebelumnya yang tentunya akan lebih efektif dan terukur. 3). Membuat produk yang tidak komersil, seringkali para pengusaha menambah fitur-fitur baru berdasarkan keinginan idealis yang tidak menambah nilai jual dan nilai tambah bagi pelanggan. Seharusnya dalam mengembangkan produk pengusaha harus berinovasi, bernilai komersil tinggi dan bisa memprediksi untuk penjualan di masa depan. 4). Tidak handal, tipe pengusaha yang tidak handal adalah seperti tidak mudah untuk merekrut tim bisnis, mengumpulkan dana, menjaring pelanggan, dan membangun kemitraan. Banyak pengusaha yang gagal dalam hal ini. Bukannya harus perfect atau tanpa kesalahan, namun akan lebih baik jika ada sesuatu yang tidak bisa dilakukan pengusaha tersebut lalu mencari solusi, bisa melalui pembicaraan dengan tim, bertanya dengan guru dalam berbisnis atau rekan yang sekiranya dapat membantu memecahkan masalah tersebut. 5). Pemilihan waktu yang kurang tepat untuk meluncur ke pasar, Hal ini adalah faktor yang paling krusial dari semua faktor karena berada diluar jangkauan kendali pengusaha. Kadang sebuah ide muncul di saat yang 
kurang tepat, dan memang sukar mempertemukan keduanya dengan tepat waktu dan sempurna. Namun hal ini dapat diatasi dengan mempertajam intuisi dan terus mengamati perkembangan yang terjadi secara cermat.

Hal diatas memberikan gambaran singkat tentang faktor penyebab kegagalan pengusaha yang banyak terlupakan. Dalam berbisnis anda akan menemui banyak sekali tantangan yang bisa diibaratkan sebagai ujian yang harus dihadapi, tantangan yang terbesar akan muncul dan biasanya itu menjadi titik balik yang sangat menentukan langkah selanjutnya.

Untuk memperoleh kesuksesan dalam menjalankan bisnis, seseorang harus memiliki idea atau visi bisnis yang jelas serta kemauan dan keberanian untuk menghadapi resiko, baik waktu maupun uang. Apabila ada kesiapan dalam menghadapi resiko, langkah berikutnya adalah membuat perencanaan usaha, mengorganisasikan, dan menjalankannya. Agar usaha tersebut berhasil, selain harus bekerja keras sesuai dengan urgensinya, juga harus mampu mengembangkan hubungan baik dengan mitrausaha maupun semua pihak yang terkait dengan kepentingan perusahaan (Suryana, 2011).

\section{PENYELESAIAN KEGAGALAN USAHA}

Jika suatu usaha menghadapi kegagalan atau kesulitan keuangan, harus diketahui dahulu apakah kesulitan keuangan tersebut bersifat jangka pendek atau jangka panjang. Kesulitan keuangan yang bersifat jangka pendek apabila tidak segera ditanggulangi dapat meimbulkan kesulitan keuangan jangka panjang. Kesulitan keuangan jangka pendek yang dimaksud adalah kesulitan dalam likuiditas perusahaan, sedagkan kesulitan jangka panjang berkaitan dengan solvabilitas perusahaan.

Terdapat beberapa cara untuk mengatasi kesulitan keuangan yang dihadapi oleh suatu perusahaan, diantaranya sebagai berikut :

1. Penyelesaian sukarela (Voluntary Settlements). Penyelesaian sukarela dapat dilakukan melalui kesepakatan antara pihak kreditur dan debitur. Ada beberapa alternative penyelesaian secara sukarela, yakni sebagai berikut :

a) Extensions (perpanjangan). Pihak kreditur sepakat dengan pihak debitur untuk memperpanjang jangka waktu jatuh tempo kredit yang telah 
diberikan. Dengan demikian, pihak debitur mempunyai kesempatan untuk memanfaatkan dana yang mestinya dipakai untuk melunasi utang guna membiayai kegiatan operasi perusahaan.

b) Composition. Para kreditur bersedia menerima pembayaran sebagian tagihannya, dan merelakan sebagian yang lainnya tidak terbayar. Atau jika para kreditur bersedia, utang tersebut diubah menjadi penyertaan modal. Hal ini akan meringankan perusahaan dari kewajiban membayar bunga dan pokok pinjaman.

c) Liquidation by voluntary agreement. Para kreditur secara bersama memutuskan meminta likuidasi perusahaan secara informal. Jika hal ini dilakukan, maka ada beberapa keuntungan yang bisa diperoleh, yaitu waktu penyelesaian likuidasi lebih cepat, biaya yang dikeluarkan lebih murah, serta nilai asset perusahaan yang dilikuidasi masih tinggi.

2. Penyelesaian Lewat Pengadilan (Settlements Involving Litigation). Apabila pihak kreditur dan debitur tidak mencapai kesepakatan untuk penyelesaian secara sukarela, maka langkah selanjutnya yang dapat ditempuh adalah penyelesaian secara hukum (Sudana, 2011).

Kesulitan keuangan yang dihadapi oleh perusahaan sangat bervariasi, mulai dari kesulitan likuiditas hingga kesulitan solvabilitas. Apabila kesulitan keuangan perusahaan bersifat permanen dan prospek perusahaan kurang baik, perusahaan dapat dilikuidasi. Jika kesulitan keuangan perusahaan bersifat sementara dan prospek perusahaan masih cukup baik, maka untuk kepentingan para kreditur, pemegang saham dan masyarakat, perusahaan dapat direorganisasi.

Likuidasi merupakan satu-satunya alternatif penyelesaian jika kondisi keuangan perusahaan sudah tidak bisa diperbaiki lagi. Pihak yang bisa mengajukan atau meminta likuidasi atau kepailitan adalah debitur, satu atau lebih debitur, dan jaksa. Keputusan pailit atau bangkrut ditetapkan oleh pengadilan (pengadilan niaga). Penjualan asset perusahaan yang sudah bangkrut biasanya dilakukan dengan cara lelang dan hasilnya dibagikan kepada para kreditur setelah dikurangi dengan biayabiaya kepailitan. Pembagian hasil likuidasi kepada kreditur dilakukan berdasarkan persentase tertentu secara pro-rata. 
Sedangkan reorganisasi adalah reorganisasi keuangan, yaitu penyusunan kembali struktur modal perusahaan, sehingga struktur modal yang baru dianggap cukup layak bagi operasi perusahaan di masa yang akan datang. Prosedur dalam reorganisasi meliputi tiga langkah, yaitu :

a. Menentukan nilai perusahaan setelah direorganisasi,

b. Menentukan struktur modal baru,

c. Menentukan nilai surat berharga lama untuk diganti dengan surat berharga baru.

Salah satu cara untuk menentukan nilai perusahaan adalah dengan jalan mengkapitalisasikan keuntungan di masa yang akan datang dengan tingkat kapitalisasi tertentu. Sedangkan penyusunan kembali struktur modal dilakukan dengan mengurangi beban mengurangi beban tetap perusahaannya dengan jalan : mengubah utang menjadi income bond, saham istimewa, dan saham biasa; Memperpanjang periode pinjaman.

Penyusunan struktur modal yang baru dipengaruhi oleh "judgement", dengan kata lain tidak ada pedoman yang pasti bahwa struktur modal harus mengikuti rumus-rumus tertentu. Penyusunan struktur modal hanya berpedoman bahwa suatu perusahaan seharusnya bekerja dengan beban keuangan tetap yang tidak terlalu besar.

\section{PROFESIONALITAS}

Pelaku usaha harus menangani usaha bisnisnya secara profesional. Hal ini akan menjamin bisnis makin besar dan langgeng. Kesalahan terjamak ialah penanganan keuangan, operasional, pemasaran, dan sumber daya manusia yang selalu menjadi momok bagi pengusaha pemula.

Keuntungan tak boleh bercampur dengan uang pribadi. Pengusaha harus cermat menghitung modal produktif, penghasilan kotor, dan keuntungan. Hitunghitungan ini memudahkan penetapan harga jual produk. Pelaku usaha sebaiknya tak mengekor harga jual produsen lain tanpa memperhatikan biaya produksinya sendiri. Dalam menjalankan usahanya, prosedur operasional haruslah ada standarnya. Ketika memasuki dunia profesional, pengusaha sudah seharusnya memiliki standardisasi. 
Banyak contoh usaha yang terhenti karena pendirinya jatuh sakit. Untuk menyiasatinya, ketika bisnis menjadi semakin besar, pelaku usaha sebaiknya mulai merekrut orang lain. Asisten, akuntan, dan kurir akan memudahkan pengembangan usaha. Memegang sebuah usaha sendirian tentu melelahkan fisik dan pikiran.

\section{KESIMPULAN}

Jalan termudah untuk menghindari kegagalan adalah dengan cara mengenali kegagalan itu sendiri. Ada berbagai faktor yang dapat menyebabkan perusahaan mengalami kegagalan, diantaranya adalah faktor ekonomi, kesalahan manajemen, dan bencana alam. Perusahaan yang mengalami kegagalan dalam operasinya akan berdampak pada kesulitan keuangan perusahaan.

Jalan terbaik ketika perusahaan mengalami kesulitan keuangan adalah dengan reorganisasi apabila prospek perusahaan masih baik, sedangkan jika perusahaan mengalami kesulitan keuangan bersifat permanen dan prospek yang buruk maka jalan keluarnya adalah lakukan likuidasi.

Untuk dapat mencapai keberhasilan, maka pelaku usaha harus memiliki sifat profesional dalam setiap aktivitasnya ketika menjalankan roda perusahaan dan pemenuhan terhadap standarisasi juga tidak boleh dilupakan.

\section{PUSTAKA ACUAN}

Akhlis, Faktor Penyebab Kegagalan Bisnis, www.ciputraentrepreneurship.com.

Benedicta Prihatin Dwi, Riyanti, Kewirausahaan Dari Sudut Pandang. Psikologi Kepribadian, Jakarta : Grasindo, 2003.

Edi Noersasongko, Analisis Pengaruh Karakteristik Individu, Kewirausahaan dan Gaya Kepemimpinan Terhadap Kemampuan Usaha Serta Keberhasilan Usaha Pada Usaha Kecil Batik di Jawa Tengah, Skripsi, Malang : Program Pascasarjana Universitas Merdeka Malang, 2005.

Henry Faizal, Noor, Ekonomi manajerial, Jakarta: PT Raja Grafindo Persada, 2007. Mono, Henny, Kegagalan dan Keberhasilan Manusia, http://sosbud.kompasiana.com. Nitisusastro, Mulyadi, Kewirausahaan dan Manajemen Usaha Kecil, Bandung : Alfabeta, 2012. 
Pranashakti, Ipan, 7 Penyebab Kegagalan Usaha Bisnis Secara Rata-Rata, http://ipan.web.id.

Primiana, Ina, Menggerakkan Sektor Riil UKM \& Industri, Bandung :Alfabeta, 2009.

Sony Heru, Priyanto, Mengembangkan Pendidikan Kewirausahaan di Masyarakat. Jurnal PNFI, 1(1), 2009.

Sudana, I Made, Manajemen Keuangan Perusahaan: Teori dan Praktik, Jakarta : Erlangga, 2011.

Suryana, Kewirausahaan, Pedoman Praktis : Kiat dan Proses Menuju Sukses, Edisi 3, Jakarta : Salemba empat : 2011.

Suyatno Purnama, Chamdan. Motivasi dan Kemampuan Usaha Dalam meningkatkan Keberhasilan Usaha Industri Kecil (Studi Pada Industri Kecil Sepatu di Jawa Timur). Jurnal Manajemen dan Kewirausahaan, 2010.

Zimmerer, Thomas W, dan Scarborough, Norman M., Essential of Entrepreneurship and Small Bisiness Management : Kewirausahaan dan Manajemen Usaha Kecil, Edisi 5, Penerjemah : Deny Arnos Kwary, (Jakarta : Salemba Empat : 2009) gagal, http://kbbi.web.id. 
Jurnal Islamiconomic Vol.6 No.1 Januari - Juni 2015 